\title{
Quarterly Update
}

National Bioenergy Center Biochemical Platform Integration Project

The Biochemical Processing Integration Task focuses on integrating the processing steps involved in enzyme-based lignocellulose conversion technology. This project supports the U.S. Department of Energy's efforts to foster development, demonstration, and deployment of "biochemical platform" biorefineries that produce inexpensive commodity sugars and fuel ethanol, as well as a variety of other fuel and chemical products, from abundant renewable lignocellulosic biomass.

The National Renewable Energy Laboratory manages this project for DOE's Office of the Biomass Program. Information on the Biomass Program is available at Biomass Program.

To discuss the content of this update or for further information on the Biochemical Processing Integration Task, contact Daniel Schell at NREL, phone (303) 384-6869, email dan_schell@nrel.gov

January-March 2008, \#18

\section{$30^{\text {th }}$ Symposium on Biotechnology for Fuels and Chemicals}

The Symposium will be held at the Astor Crowne Plaza Hotel in New Orleans, LA, from May 4-7, 2008. Meeting information can be found at the following web site: http://www.simhq.org/meetings/30symp/index.html. Session titles are listed below. Several presentations will be given by task members at this meeting covering the latest developments on NIR-based rapid compositional analysis methods and performance testing of cellulases and fermentative microorganisms.

\section{Sunday, May 4}

Session 1 - Advances in Bioenergy Feedstocks and Plant Science

Session 2 - Advances in Microbial Science and Technology I

\section{Monday, May 5}

Session 3 - Pretreatment and Biomass Recalcitrance: Fundamentals and Progress I

Session 4 - New Biofuels and Biomass Chemicals

Session 5 - Advances in Enzyme Science and Technology I

Session 6 - The New Biofuels Industry: Biomass Availability and Supply Chain

Tuesday, May 6

Session 7 - Advances in Microbial Science and Technology II

Session 8 - Pretreatment and Biomass Recalcitrance: Fundamentals and Progress II

Evening Special Topic: International Bioenergy Centers: Plans for the Future

\section{Wednesday, May 7}

Session 9 - Advances in Bioprocessing and Related Separations Technology

Session 10 - The New Biofuels Industry: Biomass Environmental Feasibility and Sustainability Session 11 - Biorefining Technology Deployment and Demonstration

Session 12 - Advances in Enzyme Science and Technology II

Please note: Due to limited poster space, the symposium organizers are requesting that at least one author on each abstract be registered to attend the Symposium before the end of preregistration. Also, if a paper is to be submitted for the Proceedings, at least one author must be registered and attend the Symposium.

\section{R\&D Progress Hionuas}

\section{Improved Analytical Method for Measuring Hydrolysate Liquor Composition}

We are working to develop new, higher-throughput analytical methods to improve both productivity and accuracy of compositional measurements. Previous issues of this newsletter discussed progress on the development of one such new HPLC method, but we have now completed validating the technique for analyzing organic acids, furans, and ethanol in lignocellulosic process streams. The new procedure is simple, precise, and accurate and reduces the normal HPLC runtime. It uses an $\mathrm{H}^{+}$form cation-exchange resin stationary phase that has a five-fold shorter analysis time compared to the traditional method. The new 


\section{Quarterly Update Bionaiass}

procedure can also be used to analyze biomass-derived sugars, but co-elution and baseline resolution issues reduce its accuracy, so the technique is more applicable as a tracking tool than as a highly quantitative method. We will soon post this method as one of our standard analytical procedures (LAP) in addition to publishing it in a journal.

\section{Work Progresses on a Rapid Compositional Analysis Method for Corn Stover Hydrolysates}

We recently completed development of a preliminary NIR-based rapid analysis method for measuring component concentrations in corn stover hydrolysate liquors. Conventional HPLC-based analysis techniques involve a multistep preparation and analysis protocol, which takes several hours to perform. By correlating highly accurate wet chemical data with near-infrared (NIR) transmission spectra of the liquor samples using multivariate statistics, we developed a calibration model that can predict the composition of liquor samples in seconds. The ability to use NIR spectroscopy for routine liquor analysis will significantly decrease the time required for this analysis. Future work will improve the model by adding more samples to make the correlations even more robust and predictive. We intend to complete this work by the end of September.

\section{Related Activities [ionuass}

\section{Sugar Loss Mechanisms During Dilute Acid Pretreatment Studied}

A paper was presented at the November 4-5 American Institute for Chemical Engineering (AIChE) 2007 Annual national meeting in Salt Lake City, UT, during the Symposium on Sustainable Biorefineries. Mark Nimlos, from NREL's Targeted Conversion Research task, presented the work in a paper entitled "Kinetics and Modeling of Xylan Hydrolysis and Xylose Dehydration and Reversion During Acid Pretreatment," which was co-authored by Mark R. Nimlos, Heidi M. Pilath, David K. Johnson, Michael E. Himmel, Xianghong Qian, and Haitao Dong (NREL). The presentation highlighted NREL's work studying losses due to dehydration and reversion reactions of xylose, an important pentose formed during dilute acid pretreatment. It is necessary to deconstruct xylans into xylose to provide access to the cellulose for enzymatic production of glucose, and high yields of xylose will help reduce the cost of the resulting bioethanol. However, the acid used to hydrolyze xylan can also catalyze xylose degradation reactions. Acid-catalyzed dehydration results in the formation of furfural. At high biomass loadings, the acid can also catalyze the recombination of xylose in what is termed a reversion reaction. Although glucose reversion reactions have been characterized in the literature, there is little information about xylose reversion reactions. NREL scientists have characterized the products and kinetics of these reactions. These results showed that reversion reactions can account for a significant loss of xylose (up to $8 \%$ ) under standard dilute acid pretreatment conditions. This information can be used to optimize the xylose yield by reducing this xylose loss reaction.

\section{Biochemical Processing Integration Task Information}

Web-based information on the process integration project, including presentations made at recent review meetings, can be found at the following links (Process Integration Project Information, http://obpreview07.govtools.us/biochem/). A discussion of how Stage Gate management is used in the Biomass Program is also available at this site ( $\underline{\text { Stage Gate Management). }}$. 


\section{Quarterly Update Bropuäss}

Produced for the

\section{U.S. Department of Energy \\ Energy Efficiency and Renewable Energy}

Bringing you a prosperous future where energy is clean, abundant, reliable, and affordable.

1000 Independence Avenue, SW, Washington, DC 20585

by the National Renewable Energy Laboratory, a DOE national laboratory

\section{A Strong Energy Portfolio for a Strong America}

Energy efficiency and clean, renewable energy will mean a stronger economy, a cleaner environment, and greater energy independence for America. Working with a wide array of state, community, industry, and university partners, the U.S. Department of Energy's Office of Energy Efficiency and Renewable Energy invests in a diverse portfolio of energy technologies.

$$
\text { DOE/GO-102008-2550 • April } 2008
$$

Printed with a renewable-source ink on paper containing at least $50 \%$ wastepaper, including $20 \%$ postconsumer waste. 